\title{
Supplier Selection Model of the Lithium-ion Battery using Fuzzy AHP and Analysis of BOCR
}

\author{
Ari Wardayanti ${ }^{1}$, Roni Zakaria ${ }^{1}$, Wahyudi Sutopo ${ }^{1,2^{*}}$, Bendjamin Benny Louhenapessy ${ }^{3}$ \\ ${ }^{1}$ Industrial Engineering Department, Faculty of Engineering, Sebelas Maret University, Surakarta, Indonesia \\ ${ }^{2}$ National Center for Sustainable Transportation Technology, Indonesia \\ ${ }^{3}$ Department of National Standardization Agency (BSN), Jakarta, Indonesia \\ *Email: wahyudisutopo@staff.uns.ac.id
}

\begin{abstract}
Although the demand for the lithium-ion battery for electronic consumers and electric vehicles in Indonesia is high, there is no supplier coming from the local manufacturer. The proper selection of suppliers is required by some lithium-ion battery manufacturers (cells, modules, and packs), and Research and Development (R\&D) center of the lithium-ion battery with the consideration not only in benefits and cost but also in opportunities and risks. It is important that experts assist the manufacturers and R\&D to procure the lithium-ion (materials and cells), through transparent methods that seek a quantitative model to select the right supplier. The main objective of this study is to propose an analytical approach to select suppliers which incorporate Benefits, Opportunities, Costs and Risks (BOCR) concept that comply with the characteristics of the lithium-ion battery industries. A fuzzy Analytical Hierarchy Process (AHP) model is developed by accommodating the vagueness and inaccuracies of expert elections. The result of this research is development of the model obtained from 2 questionnaires given to the expert. Questionnaire 1 was made for the determination of criteria and sub-criteria, while Questionnaire 2 aims to perform pairwise comparisons of existing criteria and sub-criteria. In the selection of the lithium-ion battery suppliers, there are 11 criteria and 40 sub-criteria which are considered. Those criteria are divided into 4 merits and known for their respective global priorities.
\end{abstract}

\section{Keywords}

BOCR; Fuzzy AHP; Lithium-ion battery; Supplier selection

\section{Introduction}

The development of portable electronic devices such as mobile phones, notebooks, and electric vehicles which increased significantly in the last decade, led to the need for a high capacity battery. Among the various types of chemical battery, the lithium-ion battery is one of the most promising solutions to these requirements $[1,2]$. The lithium-ion battery becomes one of the battery technology with the best energy-to-weight ratio [3] and has a relatively low self-discharging [4]. The lithiumbased battery is capable to store the energy three times larger than other materials, giving it a better competitive advantage than other battery materials as well as making it the main ingredient for the battery. Other benefits of the lithium-ion battery are higher density energy, longer lifespan, and no memory effect. [5] In addition, this battery also has a faster-charging process than NiMH battery, life cycle up to 3000 times [6], lighter, and smaller when compared to other rechargeable battery [7].

In Indonesia, the demand for the lithium-ion battery has been increasing. This can be seen from the increasing demand for portable electronic devices in which the energy storage on the device is the lithium-ion battery.
However, the increasing demand for the lithium-ion battery has not been provided by the local industries. This is due to the unavailability of the local industries to produce the lithium-ion battery. Thus, Indonesia only becomes a market for the lithium-ion battery of other countries, especially China as the main producer of the lithium-ion battery [8]. In Indonesia, the development of the lithium-ion battery is currently in the stage of assessment and development for electric vehicles [9] and other electronic devices such as power bank, battery for smartphones, and street light. This can be known from the existence of some government-owned laboratories or universities, and manufacturing companies that have started to conduct a research on development and production of the lithium-ion battery.

One of the most important factors in supporting the development and production process of the lithium-ion battery in Indonesia is the availability of materials. However, the supply of the lithium-ion battery materials in Indonesia is still limited in which most of them are still imported. From the global perspective, the number of the lithium-ion battery suppliers in the world is very high and those suppliers have potential to become suppliers for Indonesia. The supplier is able to provide 
the lithium-ion battery ranging from raw materials, lithium battery cells, modules or packs that can be directly used for electric vehicles or other products. Due to the many alternatives of existing the lithium-ion battery suppliers where each supplier has weaknesses and advantages, it is important for manufactures or Research and Development (R\&D) of the lithium-ion battery to select the right lithium-ion battery supplier. The selection of appropriate suppliers can make the entire production process goes well, produce finished products with good quality, lower purchasing costs, and enhance the competitiveness of enterprise [10].

The supplier selection process will be simple if only one criterion is used in the decision-making process. If several criteria are used, it is necessary to determine the weight of each criterion that will influence the decisionmaking process, whether they are equal or not [11]. The supplier selection problem is included in the Multiple Criteria Decision-Making (MCDM) group [12] and Analytic Hierarchy Process (AHP) which is one of the methods of MCDM.

AHP is a decision-making method which is developed to prioritize several alternatives when several criteria must be considered, and allows decision makers to construct complex problems into a hierarchy. However, AHP method has weaknesses in the inability to accommodate the disguise or uncertainty (vagueness), and the inaccuracy of respondents in making choices. For overcoming the weakness, the classical AHP method is developed into fuzzy AHP. This research will use fuzzy AHP method to solve the problem of choosing the lithium-ion battery suppliers. Fuzzy AHP is a combination of AHP and fuzzy logic. AHP method is appropriate to solve the problem because the selection of the lithium-ion battery supplier uses qualitative and quantitative criteria and sub-criteria as the basis for decision making. This method can provide guidance in determining the weight of each criterion and subcriterion. Problems of complex supplier selection such as the structure of unclear problems, unavailability of accurate data, and statistical information can be solved with this method since AHP will arrange the problem into a hierarchical form. Thus, the problem will be easily understood. In addition, fuzzy logic can accommodate the uncertainty, disguise, and inaccuracy in determining the choice.

Most of the models in supplier selection only consider the benefits derived from selecting the appropriate supplier. In fact, there are still other factors to consider such as opportunities, costs, and possible risks [13]. This also applies to the lithium-ion battery industry in selecting suppliers. The selection of the lithium-ion battery suppliers will be more effective and efficient if the aforementioned factors are considered. Based on the above problem, the purpose of this study is to develop the lithium-ion battery supplier selection model with fuzzy AHP and Benefits, Opportunities, Costs and Risks (BOCR) method to select the best supplier alternative.

\section{Literature Review}

\subsection{Supplier selection}

The selection of a supplier for partnership can be the most important step in creating a successful alliance. A careful screening of potential partners is a timeconsuming process, in addition to developing an understanding of partner expectations and objectives [14]. The selection of an appropriate supplier is an important factor affecting eventual buyer-supplier relationship. If the process is done correctly, a high quality and long-last relationship will be attainable. The selection of the type of relationship is related to a firm's market position (leader versus follower) and the strategic importance of collaborations within each firm's portfolio (core versus peripheral business) [15, $16]$.

Narasimahn [17], Nydick and Hill [18], and Partovi, et al. [19] were the earliest researchers who adopted AHP for supplier selection problems. The major reasons for applying AHP are the ability to handle both qualitative and quantitative criteria and it can be easily understood and applied by related personnel. Tam and Tummala [20] further proposed the application of AHP in a group decision-making process. Liu and Hai [21] proposed a voting AHP method, which combined AHP and Data Envelopment Analysis, for selecting supplier by comparing each weighted sum of the selection number of rank votes, after determining the weights in a selected rank. Lin and Chen [22] developed a fuzzy-decisionmaking framework to assist a company in selecting the most favorable supply chain to be allied with. Kumar, et al. [23] further developed a fuzzy multi-objective integer programming approach for vendor selection problem in a supply chain.

\subsection{Analytic hierarchy process}

AHP has become one of the most widely used methods for MCDM. It can solve unstructured problems in different areas of human needs and interests, such as political, economic, social, and management sciences. The procedures of AHP to solve a complex problem involve six essential steps which can be seen as follows [24 - 26]:

1. Define the unstructured problem and state clearly the objectives and outcomes. 
2. Decompose the problem into a hierarchical structure with decision elements (e.g., criteria and alternatives).

3. Employ pairwise comparisons among decision elements and form comparison matrices.

4. Use the eigenvalue method to estimate the relative weights of the decision elements.

5. Check the consistency of property of matrices to ensure that the judgments of decision makers are consistent.

6. Aggregate the relative weights of decision elements to obtain an overall rating for the alternatives.

\subsection{Fuzzy set theory}

Fuzzy set theory was introduced by Zadeh in 1965 to solve problems involving the absence of sharply defined criteria [27]. Because fuzziness and vagueness are common characteristics in many decision-making problems, good decision-making models should be able to tolerate vagueness or ambiguity. Thus, if the uncertainty (fuzziness) of human decision-making is not taken into account, the results from the models can be misleading. Fuzzy theory has been applied in a variety of fields since its introduction. [28]

In this study, the extent analysis method by Chang [29, 30] is adopted because the steps of this approach are relatively easy, less time-consuming, and less computational expense than other fuzzy AHP approaches. At the same time, it can overcome the deficiencies of conventional AHP. The approach not only can adequately handle the inherent uncertainty and imprecision of human decision-making process, but also can provide the robustness and flexibility needed for the decision maker to understand the problem [31]. To decide the final priority of different decision criteria, triangular fuzzy numbers are used in pairwise comparison, and the extent analysis method for the synthetic extent value of the pairwise comparison is applied.

\subsection{Benefits, opportunities, costs, and risks}

In decision-making process, there are criteria that have opposite direction to other criteria, such as criteria in benefits $(B)$ versus costs $(C)$, and criteria in opportunities $(O)$ versus risks $(R)$. Under the BOCR concept, pairwise comparison questions ask which alternative is the most beneficial or has the best opportunity under each sub-criterion/detailed criterion in $B$ and $O$ sub-networks (hierarchies) [32]. On the other hand, the pairwise comparison questions ask which alternative is the riskiest or costliest under each sub- criterion/detailed criterion in $R$ and $C$ subnets (hierarchies). The weights of alternatives are combined first according to the weights of sub-criteria detailed criteria for each subnet (hierarchy). The weights of the alternatives under $B, O, C$, and $R$ are further combined to get a single outcome for each alternative. Saaty [32] proposed five ways to combine the scores of each alternative under $B, O, C$, and $R$. The relative priority, $P i$, for each alternative is $[26,33]$ :

\section{Additive}

$$
P i=b B_{i}+o O_{i}+c\left[\left(1 / C_{i}\right)_{\mathrm{Norm}}\right]+r\left[\left(1 / R_{i}\right)_{\mathrm{Norm}}\right]
$$

where $B_{i}, O_{i}, C_{i}$ and $R_{i}$ represent the synthesized results of alternative $i$ under merits $B, O, C$ and $R$, respectively, and $b, o, c$ and $r$ are normalized weights of merit $B, O$, $C$ and $R$, respectively.

2. Probabilistic additive

$$
P i=b B_{i}+o O_{i}+c\left(1-C_{i}\right)+r\left(1-R_{i}\right)
$$

\section{Subtractive}

$$
P i=b B_{i}+o O_{i}-c C_{i}-r R_{i}
$$

\section{Multiplicative priority powers}

$$
P i=B^{b}{ }_{i}+O^{o}{ }_{i}\left[\left(1 / C_{i}\right)_{\text {Norm }}\right]^{c}\left[\left(1 / R_{i}\right)_{\text {Norm }}\right]^{r}
$$

\section{Multiplicative}

$$
P i=B_{i} O_{i} / C_{i} R_{i}
$$

The BOCR concept can be applied by either AHP or the Analytic Network Process (ANP) method. However, a major drawback of ANP method is that the questionnaire is too cumbersome. Experts usually do not have patience to fill out a long-length questionnaire, and consequently, the consistency of judgment may not be met. Therefore, in this paper, we will adopt the BOCR concept and propose a fuzzy AHP model [28].

\section{$3 \quad$ Methodology}

The method used in this research is fuzzy AHP and BOCR analysis. The steps in this study are illustrated in Figure 1. The first step is to design a Questionnaire 1 that aims to determine criteria and sub-criteria to select the lithium-ion battery supplier. The criteria and subcriteria in Questionnaire 1 also refers to studies [28] and [33] that have been adopted to suit the context of the lithium-ion battery. In Questionnaire 1, each criterion and sub criterion are grouped into each merit i.e. benefits, opportunities, costs and risks. The scale used in Questionnaire 1 is Likert scale with 1 (very 
unimportant), 2 (not important), 3 (neutral), 4 (important), and 5 (very important). The criteria and sub-criteria will enter the basis of the assessment if the average value of the election exceeds 3.75. Then the next stage is the spread of Questionnaire 2 which is a pairwise comparison questionnaire for the determination of merit weight, criteria and sub-criteria that will be used to select the lithium-ion battery suppliers which are selected in the Questionnaire 1. In the Questionnaire 2, the scale of interest linguistics AHP used is 1-9. Questionnaire 1 and Questionnaire 2 were given to respondents in $6 \mathrm{R} \& \mathrm{D}$ agencies and 5 manufacturing companies.

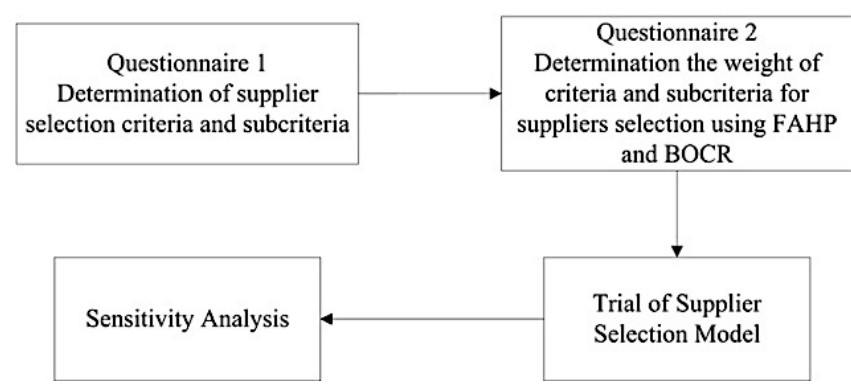

Figure 1 Approach to the study

To determine the weight of each merit, the criteria and sub-criteria steps are done by calculating the consistency ratio, changing the AHP value into Triangular Fuzzy Number, aggregation calculation, Fuzzy Synthetic Number and Degree of Possibility calculation, and the last step is the normalization of weight. The last step is to test the selection model of the lithium-ion battery suppliers by using assessment data from one of the lithium-ion battery companies who want to choose supplier. At this stage, pairwise comparisons are used to determine the most beneficial or riskiest alternative under each sub-criteria / criterion in merit benefits and risks. Furthermore, sensitivity analysis will be done to determine the effect of parameter changes on BOCR on alternative selection changes.

\section{$4 \quad$ Results and Discussion}

The questionnaires which have been disseminated to respondents who are experts in $6 \mathrm{R} \& \mathrm{D}$ agencies and 5 manufacturing companies associated with the lithiumion battery are obtained and proceed. The result of Questionnaire 1 concerning the determination of the criteria and sub-criteria that were considered in the selection of the lithium-ion battery suppliers have 40 sub-criteria considered. In the calculation phase of weighting for merit, criteria, and sub-criteria, the first step is to calculate the consistency ratio. This calculation is performed to test the pairwise comparison of each matrix element consistency. If $\mathrm{CR} \leq 0.1$ then the pairwise comparison value on the given criterion matrix is consistent. If $\mathrm{CR}>0.1$ then the pairwise comparison value on the given criterion matrix is inconsistent, so the filling of the values in matrix pairs on the criterion and alternate elements must be repeated. Based on the calculation results, it is known that all pairwise comparisons performed are consistent.

Calculations are then performed for the weight of each merit, criteria, and sub-criteria on the selection of the lithium-ion battery suppliers according to the expert. The result of the weight calculation can be seen in Table 1. Based on the calculation, the biggest merit that must be considered are the costs, followed by benefits, risks, and opportunities. This indicates the main factors which should be considered by the entities (company and R\&D) to choose a supplier is the incurred cost factor and gained benefit factor. According to the benefits, considered sub-criteria factors are yield rate, product reliability, and quality system. Meanwhile, factors that are considered for opportunities are the ease of communication, stabilized relationship with supplier, and cost reduction capability. For merit costs subcriteria, the biggest considerations are product cost, freight cost, and cost of forming relationship. And for merit risks, the biggest consideration is the supplier's capability limits, variation of price, and bargaining power of suppliers.

From the existing model of supplier selection, trial modeling is then conducted. The trials were conducted with the data assessment from one of the lithium-ion battery companies that wanted to select suppliers. The company was given 3 lithium-ion battery suppliers alternatives: Linyi Gelon Ltd (China), Targray Technology International Inc (Canada), and Xiamen Tob New Technology Ltd (China). Linyi Gelon is a retailer, while Targray Technology Int and Xiamen Tob are manufacturing companies.

The assessment with pairwise comparison is then conducted to find out the weight of each supplier in each merit. The final weight calculation to determine the best suppliers is then performed by using mathematical formula from BOCR. The result of weighting is shown in Table 2 and the final weighted result is presented in Table 3. 
Table 1 Relative priority of criteria and sub-criteria

\begin{tabular}{|c|c|c|c|}
\hline Merit & Criteria & Sub-criteria & Global Priorities \\
\hline \multirow{14}{*}{ Benefit $(30 \%)$} & \multirow{4}{*}{ Quality (74\%) } & Yield rate $(49.25 \%)$ & 0.369 \\
\hline & & Product reliability $(19.96 \%)$ & 0.148 \\
\hline & & Quality of support services (15.12\%) & 0.112 \\
\hline & & Quality system (15.67\%) & 0.116 \\
\hline & \multirow{6}{*}{ Flexibility (15\%) } & Volume flexibility $(11.12 \%)$ & 0.017 \\
\hline & & Product mix flexibility (2.98\%) & 0.004 \\
\hline & & Customizing (15.44\%) & 0.023 \\
\hline & & Process flexibility (14.37\%) & 0.022 \\
\hline & & Emergency order processing $(23.95 \%)$ & 0.036 \\
\hline & & Flexibility in Services (32.14\%) & 0.048 \\
\hline & \multirow{4}{*}{ Delivery $(11 \%)$} & Order Lead time (14.99\%) & 0.016 \\
\hline & & On time delivery $(29.14 \%)$ & 0.032 \\
\hline & & Delivery reliability $(28.82 \%)$ & 0.032 \\
\hline & & Distribution network quality $(27.06 \%)$ & 0.030 \\
\hline \multirow{10}{*}{$\begin{array}{l}\text { Opportunities } \\
(5.18 \%)\end{array}$} & \multirow{4}{*}{$\begin{array}{l}\text { Supplier's technology } \\
(28 \%)\end{array}$} & Technological system (4.34\%) & 0.012 \\
\hline & & Future technology development $(9.76 \%)$ & 0.027 \\
\hline & & Future manufacturing capabilities $(38.36 \%)$ & 0.107 \\
\hline & & Cost-reduction capability (47.54\%) & 0.133 \\
\hline & \multirow{3}{*}{ Joint growth $(20 \%)$} & $\begin{array}{l}\text { Acquisition of supplier's knowledge and } \\
\text { technology }(74 \%)\end{array}$ & 0.148 \\
\hline & & Complementary of capability (18\%) & 0.036 \\
\hline & & Joint product/technology development ( $8 \%)$ & 0.016 \\
\hline & \multirow{3}{*}{ Relationship building (52\%) } & Stabilized relationship with supplier (43\%) & 0.224 \\
\hline & & Closeness of relationship $(6 \%)$ & 0.031 \\
\hline & & Ease of communication $(51 \%)$ & 0.265 \\
\hline \multirow{5}{*}{ Cost $(36.89 \%)$} & \multirow{3}{*}{ Cost of product $(95 \%)$} & Product price $(55 \%)$ & 0.523 \\
\hline & & Freight cost $(41 \%)$ & 0.390 \\
\hline & & Extra cost $(4 \%)$ & 0.038 \\
\hline & \multirow{2}{*}{ Cost of relationship $(5 \%)$} & Cost of relationship forming (84\%) & 0.042 \\
\hline & & Time for relationship forming $(16 \%)$ & 0.008 \\
\hline \multirow{11}{*}{ Risk $(27.92 \%)$} & \multirow{3}{*}{ Supplier's constraint $(53 \%)$} & Supplier's capacity limit (10\%) & 0.053 \\
\hline & & Supplier's capability limit (70\%) & 0.371 \\
\hline & & $\begin{array}{l}\text { Supplier's raw material acquisition difficulties } \\
(21 \%)\end{array}$ & 0.111 \\
\hline & \multirow{3}{*}{$\begin{array}{l}\text { Supplier-buyer's constraint } \\
(33 \%)\end{array}$} & Variation in price $(52 \%)$ & 0.172 \\
\hline & & Bargaining Power of Supplier (45\%) & 0.149 \\
\hline & & Incompatibility between supplier-buyer ( $45 \%)$ & 0.010 \\
\hline & \multirow{5}{*}{ Supplier's profile $(14 \%)$} & Financial risk $(2.11 \%)$ & 0.003 \\
\hline & & Bad performs history and reputation $(14.17 \%)$ & 0.020 \\
\hline & & $\begin{array}{l}\text { Inadequate environment controls and programs } \\
(0.71 \%)\end{array}$ & 0.001 \\
\hline & & Geographical location (39.17\%) & 0.055 \\
\hline & & Packaging ability (43.84\%) & 0.061 \\
\hline
\end{tabular}

Based on the calculation results, it is known that supplier 1 is the best alternative choice. Supplier 1 is a trading company that sells products from other companies, so the products provided by these suppliers are very diverse. Supplier 2 and 3 become second and third choices because these suppliers are also the supplier of lithium-ion battery material, but in terms of the number of products, more products are supplied by supplier 1. The three suppliers proposed to be alternatives because they have ISO 9001 certificate which is related to the quality system. So, the products manufactured by these suppliers are conform to the standard. By choosing supplier 1, it can gain the benefits of obtaining a quality product. In addition, the payment media by supplier 1 is also more convenient compared to other suppliers, so that the company can choose the most appropriate payment media with the smallest risk. Although there are some aspects of supplier 3 which are better than supplier 1, the information availability of supplier 3 is very limited. In addition, supplier 2 is also very limited because it is located far enough with the company. As the information, supplier 1 is pretty much 
earned by the lithium-ion battery company, thus the risk that occurs due to the wrong supplier selection can be avoided. Supplier 1 is the best choice for the lithium-ion battery company. Among three suppliers, only supplier 1 has a distributor point in Indonesia that is PT KGC in Jakarta. It will facilitate the lithium-ion battery company when ordering the product in rapid quantity. So, it does not take long times in getting the product.

The analysis of sensitivity is done by using trial and error to know the change of selection alternative when the weight of BOCR is decreased or increased. The calculation of sensitivity analysis results is shown in Table 4. It is found that when the BOCR's merit weight is decreased or increased, the best choice is Supplier 1 (Linyi Gelon) and Supplier 2 (Targray). Linyi Gelon still becomes the best supplier whether the weight of merit is changed or not, while Targray can be an option only when weight of merit is changed, for example on raising of merit opportunities. Table 4 also shows the changes of the benefits and costs weights will not change the best alternatives. The decrease or increase in weight of merit will not change the best alternative option if multiplicative formula is used. This is because the multiplicative formula only accounts the weight of the supplier's assessment of the respondents, and does not account BOCR's merit weight.

Table 2 Calculation of alternative weight on each merit

\begin{tabular}{|c|c|c|c|}
\hline Alternative & $\begin{array}{c}\text { Benefit } \\
0.326\end{array}$ & $\begin{array}{c}\text { Opportunities } \\
0.091\end{array}$ & \\
\hline & Normalized & Normalized & \\
\hline Supplier 1 & 0.365 & 0.311 & \\
\hline Supplier 2 & 0.362 & 0.392 & \\
\hline Supplier 3 & 0.273 & 0.297 & \\
\hline \multirow[t]{2}{*}{ Alternative } & Costs 0.354 & & \\
\hline & Normalized & Reciprocal & Normalized \\
\hline Supplier 1 & 0.282 & 3.548 & 0.381 \\
\hline Supplier 2 & 0.292 & 3.424 & 0.367 \\
\hline Supplier 3 & 0.426 & 2.347 & 0.252 \\
\hline \multirow[t]{3}{*}{ Total } & & 9.319 & \\
\hline & Risk 0.2296 & & \\
\hline & Normalized & Reciprocal & Normalized \\
\hline Supplier 1 & 0.267 & 3.742 & 0.401 \\
\hline Supplier 2 & 0.422 & 2.368 & 0.254 \\
\hline Supplier 3 & 0.310 & 3.221 & 0.345 \\
\hline Total & & 9.331 & \\
\hline
\end{tabular}

Table 3 Final synthesis of alternative priorities

\begin{tabular}{lccccc}
\hline Alternative & Additive & $\begin{array}{c}\text { Probabilistic } \\
\text { additive }\end{array}$ & Rank \\
Supplier 1 & Priority & Rank & Priority & 1 & 3 \\
Supplier 2 & 0.374 & 1 & 0.569 & 2 & Multiplicative \\
Supplier 3 & 0.342 & 3 & 0.537 & Priority \\
\hline Alternative & 0.284 & 2 & Multiplicative & & 1.507 \\
& Subtractive & & priority powers & 1.152 \\
Supplier 1 & Priority & -0.014 & 1 & 0.373 & 2 \\
Supplier 2 & -0.047 & 3 & 0.338 & 2 & 2 \\
Supplier 3 & -0.106 & 2 & 0.282 & 3 & 3 \\
\hline
\end{tabular}


Table 4 Sensitivity of analysis under different priorities of merits

\begin{tabular}{|c|c|c|c|c|c|c|c|c|}
\hline \multirow{2}{*}{$\begin{array}{c}\text { Merits } \\
\text { Merit Weight } \\
\text { changes }\end{array}$} & \multicolumn{4}{|c|}{ Benefits (0.30) } & \multicolumn{4}{|c|}{ Opportunities (0.0518) } \\
\hline & \multicolumn{2}{|c|}{$b$ (decreases) } & \multicolumn{2}{|c|}{$b$ (increases) } & \multicolumn{2}{|c|}{$o$ (decreases) } & \multicolumn{2}{|c|}{$o$ (increases) } \\
\hline & $b$ & $\begin{array}{c}\text { Best } \\
\text { alternative(s) }\end{array}$ & $b$ & $\begin{array}{c}\text { Best } \\
\text { alternative(s) }\end{array}$ & $o$ & $\begin{array}{c}\text { Best } \\
\text { alternative(s) }\end{array}$ & $o$ & $\begin{array}{c}\text { Best } \\
\text { alternative(s) }\end{array}$ \\
\hline Additive & N/A & Supplier 1 & N/A & Supplier 1 & N/A & Supplier 1 & 0.326 & Supplier 1,2 \\
\hline $\begin{array}{l}\text { Probabilistic } \\
\text { additive }\end{array}$ & N/A & Supplier 1 & N/A & Supplier 1 & $\mathrm{~N} / \mathrm{A}$ & Supplier 1 & 0.329 & Supplier 1,2 \\
\hline Subtractive & N/A & Supplier 1 & N/A & Supplier 1 & N/A & Supplier 1 & 0.329 & Supplier 1,2 \\
\hline $\begin{array}{l}\text { Multiplicative } \\
\text { priority powers }\end{array}$ & N/A & Supplier 1 & $\mathrm{~N} / \mathrm{A}$ & Supplier 1 & $\mathrm{~N} / \mathrm{A}$ & Supplier 1 & 0.338 & Supplier 1,2 \\
\hline Multiplicative & N/A & Supplier 1 & N/A & Supplier 1 & N/A & Supplier 1 & $\mathrm{~N} / \mathrm{A}$ & Supplier 1 \\
\hline Merits & \multicolumn{4}{|c|}{ Costs (0.3689) } & \multicolumn{4}{|c|}{ Risks (0.2792) } \\
\hline $\begin{array}{l}\text { Merit Weight } \\
\text { changes }\end{array}$ & \multicolumn{2}{|c|}{$c$ (decreases) } & \multicolumn{2}{|c|}{$c$ (increases) } & \multicolumn{2}{|c|}{$r$ (decreases) } & \multicolumn{2}{|c|}{$r$ (increases) } \\
\hline & $c$ & $\begin{array}{c}\text { Best } \\
\text { alternative(s) }\end{array}$ & $c$ & $\begin{array}{c}\text { Best } \\
\text { alternative(s) }\end{array}$ & $r$ & $\begin{array}{c}\text { Best } \\
\text { alternative(s) }\end{array}$ & $r$ & $\begin{array}{c}\text { Best } \\
\text { alternative(s) }\end{array}$ \\
\hline Additive & $\mathrm{N} / \mathrm{A}$ & Supplier 1 & N/A & Supplier 1 & 0.0394 & Supplier 1,2 & $\mathrm{~N} / \mathrm{A}$ & Supplier 1 \\
\hline $\begin{array}{l}\text { Probabilistic } \\
\text { additive }\end{array}$ & N/A & Supplier 1 & N/A & Supplier 1 & 0.0392 & Supplier 1,2 & N/A & Supplier 1 \\
\hline Subtractive & N/A & Supplier 1 & N/A & Supplier 1 & 0.0449 & Supplier 1,2 & $\mathrm{~N} / \mathrm{A}$ & Supplier 1 \\
\hline $\begin{array}{l}\text { Multiplicative } \\
\text { priority powers }\end{array}$ & N/A & Supplier 1 & N/A & Supplier 1 & 0.0388 & Supplier 1,2 & N/A & Supplier 1 \\
\hline Multiplicative & N/A & Supplier 1 & N/A & Supplier 1 & $\mathrm{~N} / \mathrm{A}$ & Supplier 1 & $\mathrm{~N} / \mathrm{A}$ & Supplier 1 \\
\hline
\end{tabular}

\section{Conclusion}

We have produced a selection model of the lithium-ion battery suppliers using fuzzy AHP and BOCR analyses. Choosing the best suppliers can make the entire production process goes well, produce quality finished products, lower purchasing costs, and improve competitiveness. In selection of the lithium-ion battery suppliers, 11 criteria and 40 sub-criteria are considered. The criteria and sub-criteria are divided into 4 merits: benefits, opportunities, costs and risks. In choosing suppliers, the main considerations are the incurred cost factor, the gained benefits, the risks, and opportunities. According to the benefits, sub-criteria factors that must be considered are yield rate, product reliability and quality system. Meanwhile, according to the opportunities, sub-criteria factors that must be considered are the ease of communication, stabilized relationship with supplier, and cost reduction capability. For merit costs sub-criteria, the biggest consideration is the product cost, freight cost, and cost of forming relationship. For merit risks, the biggest consideration are the supplier's capability limits, variation in price, and bargaining power of suppliers. The sensitivity analysis is conducted by increasing and decreasing the merit weight. It is known that there is no change of alternative choices in merit benefits and opportunities. In contrast, costs and risks produce the different alternative choices. These should be considered in the selection of the lithium-ion battery suppliers.

\section{Acknowledgment}

This paper is supported by USAID through Sustainable Higher Education Research Alliances (SHERA) Program - Centre for Collaborative (CCR) National Center for Sustainable Transportation Technology (NCSTT) with grant no. IIE00000078-ITB-1.

\section{References}

[1] C. A. Vincent, "Lithium batteries: a 50-year perspective, 1959-2009," in Solid State Ionic, vol. 134, pp. 159-167, October 2000.

[2] M. Wakihara, "Recent development in the lithium-ion batteries," Material Science and Engineering, vol. 33, pp. 109134, June 2001.

[3] Nipress, "The explanation from research and development department of PT Nipress tbk," Bogor, August 2015.

[4] Sumiati and T. Sugiharto, "Studi kelayakan proyek pengembangan perkebunan pisang abaca dengan menggunakan analisis peranggaran modal," Jurnal Ekonomi dan Bisnis, vol. 7, pp. 145 - 150, 2002.

[5] F. Davies, "The lithium market," September 2013.

[6] W. Sutopo, N. A. Atikah, A. Purwanto, and M. Nizam, "The battery $10 \mathrm{kWh}$ : a financial analysis of mini manufacturing plant," in Joint International Conference on Rural Information \& Communication Technology \& Electric-Vehicle Technology. 2013.

[7] W. Sutopo, D. M. Indah, A. Purwanto, and M. Nizam, “A comparative value chain analysis of battery technologies for electric vehicle," In Joint International Conference on Rural Information \& Communication Technology \& ElectricVehicle Technology, 2013.

[8] Y. Kasumaningrum, "Baterai litium-ion jadi industri strategis" in http://www.b4t.go.id/blog/2016/05/26/baterai-litium-ionjadi-industri-strategis/, 2016. [accessed on May 29, 2017] 
[9] Badan Pengkajian dan Penerapan Teknologi, "Kajian roadmap pengembangan energy storage untuk smart grid system," Pusat Teknologi Konversi dan Konservasi Teknologi, 2013.

[10] S. H. Ghodyspour and C. O'Brien, "The total cost of logistics in supplier selection, under conditions of multiple sourcing, multiple criteria and capacity constraint," International Journal of Production Economics, vol. 73, pp. 15-27, 2009.

[11] R. Rahmayanti, "Analisis pemilihan supplier menggunakan metode analytical hierarchy process (AHP) (Studi Kasus Pada PT Cazikhal)," Economy Faculty, Sebelas Maret University, 2010.

[12] S. Yahya and B. Kingsman, "Vendor rating for an entrepreneur development programme: a case study using the analytic hierarchy process method," Journal of the Operational Research Society, vol. 50, pp. 916-930, 1999.

[13] C. Chen-Tung, L. Ching-Torng and S. F. Huanget, "A fuzzy approach for supplier evaluation and selection in supply chain management," Production Economics, vol. 102, pp. 289-301, 2006.

[14] M. T. Dacin and M. A. Hitt, "Selecting partners for successful international alliances: Examination of US and Korean firms," Journal of World Business, vol. 32, pp. 3-16, 1997.

[15] P. Lorange and J. Roos, Strategic alliances: Formation, implementation, and evolution. Cambridge: Blackwell Business, 1993.

[16] E. Todeva and D. Knoke, "Strategic alliances and models of collaboration," Management Decision, vol. 43, pp. 123-148, 2005.

[17] R. Narasimahn, "An analytical approach to supplier selection," Journal of Purchasing and Materials Management, vol. 19, pp. 27-32, 1983.

[18] R. L. Nydick and R. P. Hill, "Using the analytic hierarchy process to structure the supplier selection procedure," Journal of Purchasing and Materials Management, vol. 25, pp. 31-36, 1992.

[19] F. Y. Partovi, J. Burton, and A. Banerjee, "Application of analytic hierarchy process in operations management," International Journal of Operations and Production Management, vol. 10, pp. 5-19, 1989.

[20] M. C. Y. Tam and V. M. R. Tummala, "An application of the AHP in vendor selection of a telecommunications system," Omega: The International Journal of Management Science, vol. 29, pp. 171-182, 2001.
[21] C. W. R. Lin and H. Y. S. Chen, "A fuzzy strategic alliance selection framework for supply chain partnering under limited evaluation resources," Computers in Industry, vol. 55, pp. 159-179, 2004.

[22] F. H. F. Liu and H. L. Hai, "The voting analytic hierarchy process method for selecting supplier," International Journal of Production Economics, vol. 97, pp. 308-317, 2005.

[23] M. Kumar, P. Vrat, and R. Shankar, "A fuzzy goal programming approach for vendor selection problem in a supply chain," Computers \& Industrial Engineering, vol. 46, pp. 69-85, 2004.

[24] C. H. Cheng, "Evaluating weapon systems using ranking fuzzy numbers," Fuzzy Sets and Systems, vol. 107, pp. 25-35, 1999.

[25] A. H. I. Lee, H. Y. Kang, and W. P. Wang, "Analysis of priority mix planning for semiconductor fabrication under uncertainty," International Journal of Advanced Manufacturing Technology, vol. 28, pp. 351-361, 2006.

[26] A. H. I. Lee, "A fuzzy AHP evaluation model for buyersupplier relationships with the consideration of benefits, opportunities, costs and risks," International Journal of Production Research, vol. 47, pp. 4255-4280, 2009.

[27] L. A. Zadeh, "Fuzzy sets", Information and Control, vol. 8, pp. 338-353. 1965.

[28] A. H. I. Lee, "A fuzzy supplier selection model with the consideration of benefits, opportunities, costs and risks," Expert System with Applications, vol. 36, pp. 2879-2893, 2009

[29] D. Y. Chang, "Extent analysis and synthetic decision," Optimization Techniques and Applications, vol. 1, pp. 352355, 1992.

[30] D. Y. Chang, "Applications of the extent analysis method on fuzzy AHP," European Journal of Operational Research, vol. 95, pp. 649-655, 1996.

[31] F. T. S. Chan and N. Kumar, "Global supplier development considering risk factors using fuzzy extended AHP-based approach," Omega: The International Journal of Management Science, vol. 35, pp 417-431, 2007.

[32] T. L. Saaty, Decision making in complex environment: The analytic hierarchy process (AHP) for decision making and the analytic network process (ANP) for decision making with dependence and feedback, Pittsburgh: Super Decisions, 2003.

[33] G. W. Dickson, "An analysis of vendor selection system and decision," Journal of Purchasing, vol. 2, 1966. 